\title{
Detecting and predicting neutralization of alemtuzumab responses in MS
}

Gauri Saxena, BSc, ${ }^{*}$ James M. Moore, MBBS,* Meleri Jones, PhD, Gareth Pryce, PhD, Liaqat Ali, PhD, Georgia R. Leisegang, MSc, Vivek Vijay, MBBS, Samantha Loveless, PhD, Neil P. Robertson, MD, Klaus Schmierer, PhD, Gavin Giovannoni, PhD, Sharmilee Gnananpavan, PhD, David Baker, PhD, Emma C. Tallantyre, PhD, * and Angray S. Kang, PhD*

Neurol Neuroimmunol Neuroinflamm 2020;7:e767. doi:10.1212/NXI.0000000000000767
Correspondence

Dr. Kang

a.s.kang@qmul.ac.uk

\section{Abstract}

\section{Objective}

To test the hypothesis that antidrug antibodies (ADAs) against alemtuzumab could become relevant after repeated treatments for some individuals, possibly explaining occasional treatment resistance.

\section{Methods}

Recombinant alemtuzumab single-chain variable fragment antibody with a dual tandem nanoluciferase reporter linker was made and used to detect binding ADAs. Alemtuzumab immunoglobulin G Alexa Fluor 488 conjugate was used in a competitive binding cell-based assay to detect neutralizing ADAs. The assays were used to retrospectively screen, blinded, banked serum samples from people with MS $(n=32)$ who had received 3 or more cycles of alemtuzumab. Lymphocyte depletion was measured between baseline and about 1 month postinfusion.

\section{Results}

The number of individuals showing limited depletion of lymphocytes increased with the number of treatment cycles. Lack of depletion was also a poor prognostic feature for future disease activity. ADA responses were detected in 29/32 (90.6\%) individuals. Neutralizing antibodies occurred before the development of limited depletion in $6 / 7$ individuals (18.8\% of the whole sample). Preinfusion, ADA levels predicted limited, postinfusion lymphocyte depletion.

\section{Conclusions}

Although ADAs to alemtuzumab have been portrayed as being of no clinical significance, alemtuzumab-specific antibodies appear to be clinically relevant for some individuals, although causation remains to be established. Monitoring of lymphocyte depletion and the antidrug response may be of practical value in patients requiring additional cycles of alemtuzumab. ADA detection may help to inform on retreatment or switching to another treatment.

From the Blizard Institute (G.S., M.J., G.P., L.A., G.R.L., V.V., K.S., G.G., S.G., D.B., A.S.K.), Barts and The London School of Medicine and Dentistry, Queen Mary University of London; Division of Psychological Medicine and Clinical Neurosciences (I.M.M., S.L., N.P.R., E.C.T.), Cardiff University School of Medicine, United Kingdom; Department of Biological Sciences (L.A.), National University of Medical Sciences, Rawalpindi, Pakistan; Centre for Oral Immunobiology and Regenerative Medicine (G.R.L., A.S.K.), Institute of Dentistry, Barts and The London School of Medicine and Dentistry, Queen Mary University of London; Clinical Board:Medicine (Neuroscience) (V.V., K.S., G.G., S.G.), The Royal London Hospital, Barts Health NHS Trust; and Welsh Neuroscience Research Tissue Bank (S.L., N.P.R.), Cardiff University, United Kingdom. 


\section{Glossary}

ADA = antidrug antibody; DMT = disease-modifying treatment; EDSS = Expanded Disability Status Scale; PwMS = people with MS; WNRTB = Welsh Neuroscience Research Tissue Bank.

MS is an immune-mediated, demyelinating disease of the CNS. Memory $\mathrm{T}$ and B lymphocytes are key in the pathophysiology of MS, and these cell types are targeted by an increasing number of disease-modifying treatments (DMTs) capable of inhibiting relapsing MS. These DMTs are administered continuously or given as a pulsed immune reconstitution therapy to produce long-term disease inhibition. ${ }^{1}$ Alemtuzumab was the first biological immune reconstitution therapy licensed for the treatment of people with MS (PwMS). ${ }^{1,2}$ This depletes lymphocytes in vivo and in vitro by a number of mechanisms, including complement fixation and antibody-dependent cellular cytotoxicity, ${ }^{1,2}$ and has been shown to be highly efficacious in suppressing relapses in PwMS (Comparison of Alemtuzumab and Rebif Efficacy in Multiple Sclerosis Study One and Two [CARE MS I and II]). ${ }^{3,4}$ However, a small number of people appear to be unresponsive to alemtuzumab and continue to experience clinical relapses despite treatment. ${ }^{5}$

Although alemtuzumab was the first humanized monoclonal antibody engineered with the aim of reducing immunogenicity to the founding rodent molecule, ${ }^{6}$ surprisingly, it is one of the most immunogenic therapeutic proteins ${ }^{7,8}$ generating antidrug antibodies (ADAs), which may be either binding or neutralizing. ${ }^{8}$ Yet, these have been reported to be of minimal clinical significance. ${ }^{9-11}$ Indeed, the dosing schedule of alemtuzumab ${ }^{9-12}$ avoids issues of $\mathrm{ADA}$, which occur with high frequency $(\sim 85 \%)$ within 2 years of treatment. ${ }^{13-15}$ Using the currently recommended treatment schedule, the infusion cycle ends before primary and secondary antibody responses will be generated, and the recommended interval of at least 12 months between treatment cycles allows ADA levels to subside. ${ }^{7,13}$ Neutralizing ADAs were not mentioned in the pivotal trial reports. ${ }^{10-12}$ These only occurred in $0.6 \%$ of PwMS before the second infusion cycle, ${ }^{7}$ so would be infrequently problematic within the original 2-year treatment cohort. ${ }^{1,10,11}$ However, as additional treatment cycles were shown to be efficacious in people not adequately responding to 2 cycles, ${ }^{3,4,15}$ the European Medicines Agency supported the use of third and fourth treatment cycles in 2017. However, predose binding and neutralizing ADA become far more prevalent following the second treatment cycle ( $75 \%$ and $31 \%$ at 24 months, respectively), a factor which may limit the biological and clinical efficacy of the subsequent treatment cycles. ${ }^{7,8}$ In this study, we investigated the hypothesis that ADAs become increasingly problematic after successive cycles of alemtuzumab treatment and that the ADA levels may be associated with diminished treatment effectiveness.

\section{Methods}

\section{ADA assays}

To monitor PwMS in our care, we developed an in-house luminescence-based, antiglobulin detection assays for binding anti-alemtuzumab-specific antibodies. ${ }^{16}$ In brief, a recombinant single-chain variable fragment based on alemtuzumab variable heavy and light chains was engineered as a fusion protein with 2 nanoluciferase reporter domains (GloBody). In the presence of ADAs, GloBodyADA complexes form which are captured on immobilized protein-G and the retained luciferase activity measured. ${ }^{16}$ In addition, competitive binding of Alexa Fluor 488-labeled alemtuzumab to adherent human CD52-expressing Chinese hamster ovary cells, coupled with serial dilutions of serum, was used as a neutralizing assay. ${ }^{17}$ Detailed methodology has been reported previously. ${ }^{16,17}$

\section{Ethical approval}

Samples were collected with informed consent and ethical approval (Research Ethics Committee approval references: 19/WA/0058 and 05/WSE01/11).

\section{Alemtuzumab treatment}

People received 5 daily $12 \mathrm{mg}$ infusions at baseline and 3 daily $12 \mathrm{mg}$ infusions where administered 12 months later ${ }^{11}$. Following disease activity (typically $\geq 1$ relapse and/ or $\geq 2$ unique lesions defined as either new/enlarging T2 hyperintense and/or gadolinium-enhancing brain and/or spinal cord lesions via MRI), additional cycles of 3 daily $12 \mathrm{mg}$ infusions could be administered at least 12 months apart. $^{3,4}$

\section{Samples}

The assays were applied to bioarchived serum samples from 32 PwMS who had all received 3 or more cycles of alemtuzumab. ${ }^{5}$ Samples were obtained from the Welsh Neuroscience Research Tissue Bank (WNRTB) and had been donated as part of a long-running population study of MS, which has previously been described. ${ }^{18}$ Analysis of ADA was performed blinded to clinical and laboratory data from the WNRTB. Individuals had received $3(\mathrm{n}=24), 4$ $(\mathrm{n}=3), 5(\mathrm{n}=4)$, or $6(\mathrm{n}=1)$ cycles of alemtuzumab. Absolute lymphocyte counts, taken from routine laboratory reports where available, from time points immediately before, and 1-2 month after each infusion, were used to calculate relative depletion rates. Apparent lymphocyte depletion was defined as $\geq 35 \%$ reduction in absolute lymphocyte count pre- to postinfusion and/or depletion below the lower limit of normal. 


\section{Statistical analysis}

Statistical analysis was performed using the $t$ test/MannWhitney $U$ tests using Sigmaplot Software (Systat, San Jose, CA).

\section{Data sharing}

Anonymous data are available on request.

\section{Results}

\section{Cohort characteristics}

At the time of sample requisition from the WNRTB, 137 people had received alemtuzumab within the South Wales cohort. In total, 40 people had received 3 or more treatment cycles of alemtuzumab. The rates of receiving a third (or subsequent treatment) in this cohort was $49 \%(39 / 80)$ of people followed up to 5 years and 50\% (15/30) of people followed up to 10 years. Archived blood samples were available from 32 of the total 40 individuals who had ever received a third cycle of treatment. The 32 people who had donated blood samples were 28 female $(88 \%)$ and had a mean age at MS onset of 29 years (range 10-44 years). All PwMS received alemtuzumab as first-line treatment; the first cycle was administered after a mean duration of 4.5 years (range 0.6-17 years) from symptom onset.

\section{Individuals do not deplete lymphocytes on repeated infusion of alemtuzumab}

Lymphocyte depletion data were available for 32 of 32 (cycle 1 ), 32 of 32 (cycle 2), and 31 of 32 (cycle 3). At the population level, lymphocyte depletion was marked and significant $(p<$ 0.001 ) compared with precycle treatment levels for cycle 1 to cycle 3 (figure 1). However, at an individual level, 31 of 32 people (97\%) showed apparent lymphocyte depletion following cycle 1, 30 of 32 (94\%) after cycle 2, and 27 of 31 (87\%) after cycle 3 in PwMS (figure 1). Of the 4 people who did not show apparent lymphocyte depletion after cycle 3, 2 had previously shown limited depletion after cycle 2 . Lymphocyte subset analysis was not available. Although it is recognized that these counts will reflect a composite of depleted and repopulating cells, ${ }^{7}$ whose composition may change due to the different reconstitution kinetics of distinct lymphocyte subsets, ${ }^{7}$ relative lack of depletion may be an indicator for the lack of efficacy of alemtuzumab due to antibody neutralization.

\section{ADA responses occur with high frequency}

Baseline serum samples were available for 17/32 PwMS. Using a binding ADA assay, ${ }^{16}$ low titers $751 \pm 1,399$ Lux were evident in subjects before the first infusion (figure 2). However, 29/32 (90.6\%) people generated binding ADA with a titer $>2$ SDs above the baseline mean $(>3,549$ Lux) during their subsequent follow-up (figure 2). Some people demonstrated very high ADA titers (mean 1,288,805 $\pm 2,773,146$ Lux with a range 1,296-9,965,386 Lux) following alemtuzumab treatment (figures 2 and 4). A standard monoclonal antialemtuzumab immunoglobulin G (Bio-Rad HCA-199) spiked into control serum at $\sim 50 \mu \mathrm{g} / \mathrm{mL}$ generated a signal of 21,159 $\pm 6,468$ Lux. The maximum blood concentration range of alemtuzumab immediately after the third infusion is $2.3 \pm$ $0.8 \mu \mathrm{g} / \mathrm{mL}^{14}$; ADA values in the range of the spiked standard would be theoretically at least 16 -fold molar excess of the circulating levels of the drug.

\section{Relationship between lymphocyte depletion, ADAs, and treatment response}

ADAs were clearly present in $6 / 7$ individuals before poor depletion occurred. Binding ADA titers were boosted with each cycle of treatment, and the binding ADA became persistent in some individuals (figure 3, A-D). This was associated with increasing levels of antibody neutralization (figure 3 , A-D). One individual appeared to demonstrate limited lymphocyte depletion despite an absence of neutralizing ADA (figure 3E). However, in this case, month 1

Figure 1 Lymphocyte depletion following alemtuzumab treatment

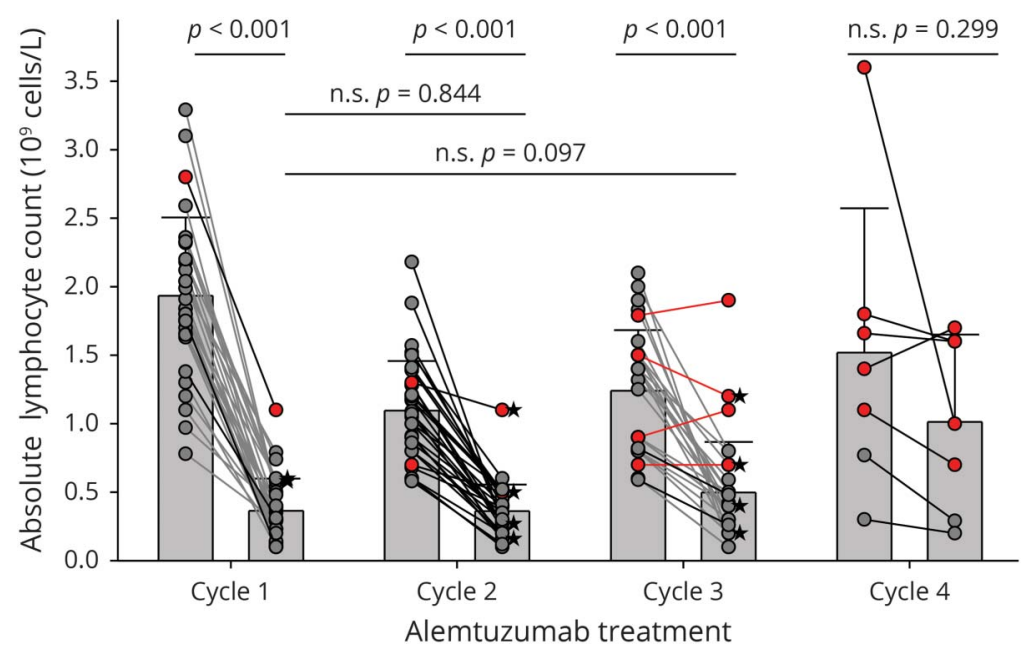

PwMS received 3 cycles $(n=31)$. Few of these individuals received 4 cycles $(n=7)$ of alemtuzumab. The figures represent the mean and SD of absolute peripheral blood lymphocyte count and the individual levels before and after treatment for each treatment cycle. Those with depletion that perhaps suggests atypical/insufficient (low change or absolute depletion level above the lower limit of normal) depletion (red) compared with those depleting (gray) are indicated. In some individuals (black filled star), postdose blood counts were more than 2 months from infusion. Statistical analysis was performed using the $t$ test/Mann-Whitney $U$ tests. PwMS = people with MS. 
Figure 2 High-titer ADAs develop in most people following alemtuzumab treatment

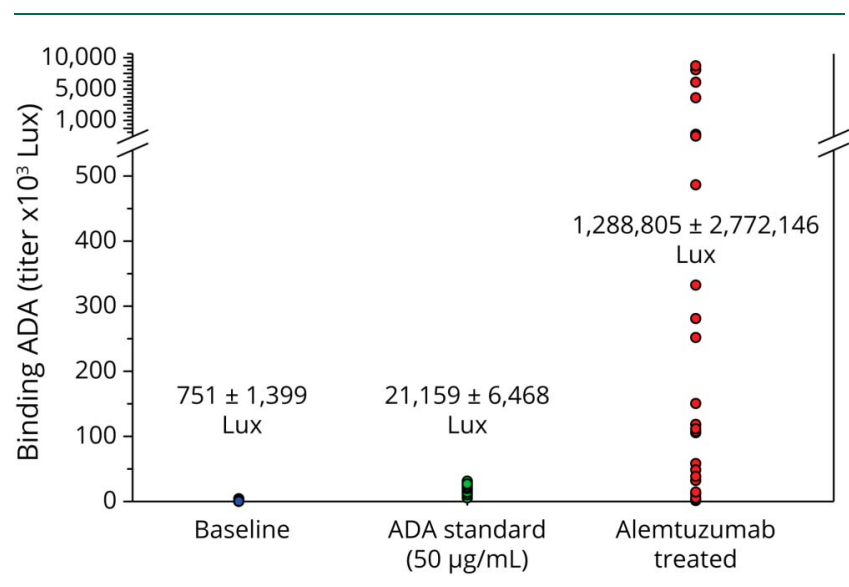

Alemtuzumab GloBody was used to detect binding ADA in sera from PwMS who had received alemtuzumab. The results show individual baseline responses before the initial infusion (blue; $n=17$ ), the response to a $50 \mu \mathrm{g}$ / $\mathrm{mL}$ alemtuzumab ADA monoclonal antibody standard (Bio-Rad HCA-199, green; $n=32$ ), and the highest titer for each individual (red; $n=32$ ) in any of 4-6 samples/individual banked during treatment. The mean \pm SD group scores are shown. ADA = antidrug antibody; PwMS = people with MS.

postinfusion lymphocyte data were unavailable. Lymphocyte levels were first measured more than 2.5 months postinfusion, so we cannot exclude the possibility that depletion, followed by rapid repletion, occurred within this time window. Six of 7 individuals who depleted poorly exhibited disease activity within 2 years of infusion. In contrast, it was evident that only 13/28 PwMS with apparent lymphocyte depletion demonstrated disease activity after 3 cycles, with 14/16 people without disease activity having $>5$ years of follow-up. People receiving 4 cycles (figure $3 \mathrm{n}=7 / 7$ ) of alemtuzumab subsequently exhibited disease activity in this cohort. This study was not designed to monitor the clinical significance of antibody neutralization. However, when comparing baseline and 5-year Expanded Disability Status Scale (EDSS) scores, those who neutralized the alemtuzumab response after 3 cycles of treatment showed a median 1.0 point EDSS worsening (range 0.5-2.0, $\mathrm{n}=5$ ), whereas those who did not develop neutralizing antibodies showed a median improvement of 0.5 EDSS points (range -2.0 to $2.5, \mathrm{n}=26$ ). This may suggest that antibody neutralization has clinical significance, but further studies are warranted.

\section{Predose ADA responses may detect subsequent lymphocyte depletion responses}

As it is known that most people generate $\mathrm{ADA}$ that wanes over time (figure 3, B-D), ${ }^{7,8,14}$ precycle $\mathrm{ADA}$ levels and the subsequent lymphocyte depletion level will be most informative on the significance of $\mathrm{ADA} .^{7,8}$ However, only 23 serum samples from 19 different individuals with lymphocyte depletion data were taken less than 2 months before infusion. This included 5 predose samples from poor-depleting individuals whose $\mathrm{ADA}$ titers were $2.7 \times 10^{4}, 2.8 \times 10^{4}, 8.9 \times 10^{4}, 1.2 \times 10^{5}$, and $1.0 \times 10^{6}$ Lux units (figure 3). Many people who depleted lymphocytes exhibited low-titer (below $1.5 \times 10^{3}$ Lux units) antibody responses (figure 4A); however, there were individuals who had relatively high titers $\left(5.8 \times 10^{4}\right.$ and $1.1 \times 10^{5}$ Lux units $)$ of binding $\mathrm{ADA}$ but exhibited notable depletion (1.4-0.2, 1.8 to 0.4 cells $10^{9} / \mathrm{L}$. Figure $4 \mathrm{~A}$ ) and did not relapse for at least 4 and 7 years after infusion. However, these individuals did not exhibit neutralizing potential (figure 4, B and C). Therefore, binding $(<15,000 \mathrm{Lux})$ and neutralizing ( $\geq 10$ titer for virtually complete neutralization) titers perhaps could be adopted to suggest poor depleters and depleters (figure 4A). It remains to be established whether this can be applied prospectively, but the data suggest that it is possible that predose $\mathrm{ADA}$ titer limits may be set that can exclude potential futile treatments.

\section{Discussion}

Alemtuzumab is a potent immune reconstitution therapy; however, up to $40 \%-50 \%$ of people receiving alemtuzumab for MS require 3 or more cycles of treatment., ${ }^{5,15}$ Third and subsequent cycles are often followed by a sustained remission of disease activity, ${ }^{4,15}$ but cases are recognized to occur where people are unresponsive to alemtuzumab and continue to experience clinical relapses despite treatment. During the clinical development of alemtuzumab, the effect of neutralizing antibodies was not mentioned, and $\mathrm{ADAs}$ have been repeatedly portrayed as being clinically insignificant. ${ }^{11,12,19}$

However, our study suggests that some people develop persistent neutralizing antibody responses to alemtuzumab and that this is associated with limited lymphocyte depletion and disease activity. Although it is not possible to prove cause and effect, it seems likely that high-titer neutralizing responses would blunt or inhibit the lymphocyte depletion response. In this study, 6/32 (18.8\%) developed high titers of both binding and neutralizing ADAs and showed subsequent evidence of relative lack of lymphocyte depletion. This is aligned with other reports in the literature of disease activity requiring further infusions associated with lack of lymphocyte depletion, which prompts switching to another DMT. $^{20}$ However, there are alternative explanations to explain poor depletion and disease breakthrough, such as alemtuzumab treatment leading to the emergence of CD52negative lymphocytes. ${ }^{21,22}$ This may have contributed to poor depletion despite limited ADA response in 1 individual. Furthermore, pharmacogenomics, such as Fc receptor genetic variants, linking to antibody-dependent cellular cytotoxicity, may also be relevant, particularly if antibody titers become limiting. ${ }^{1,23-25}$

Although the precise molecular mechanisms that cause the formation of $\mathrm{ADA}$ remain to be defined, it is evident that the majority of people produce CD52-specific ADA following alemtuzumab infusion. ${ }^{7,13}$ This probably relates to a number of factors that include the dose, dosing schedule, biology of alemtuzumab, CD52 expression profile, and the repopulation kinetics of ADA forming cells and CD52-expressing regulatory subsets. ${ }^{26}$ These ADAs are boosted with an increasing number of infusions such that they become relatively persistent in some individuals. ${ }^{7,13}$ Further prospectively collected 
Figure 3 Alemtuzumab neutralizing responses appear before PwMS apparently fail to deplete lymphocytes
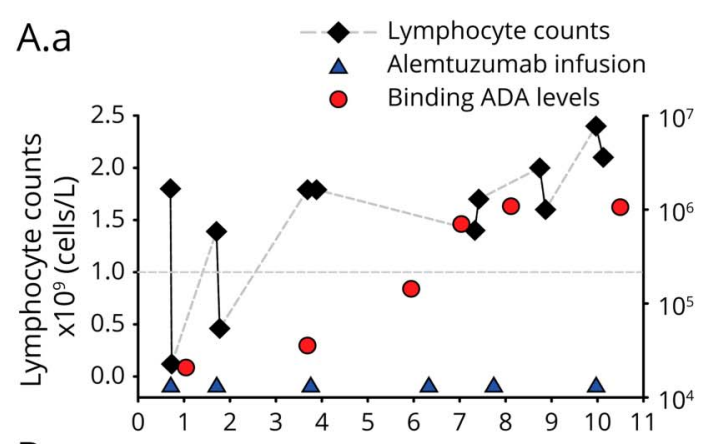

B.a

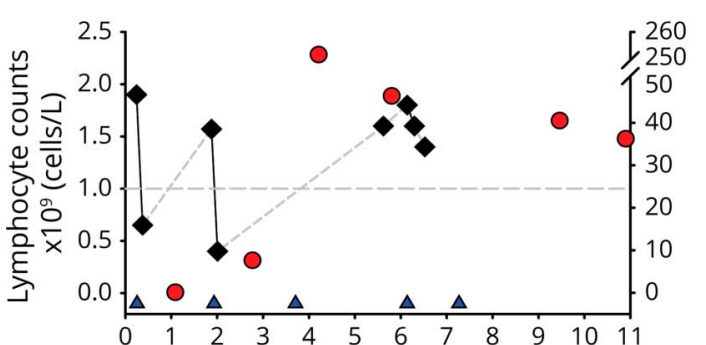

C.a

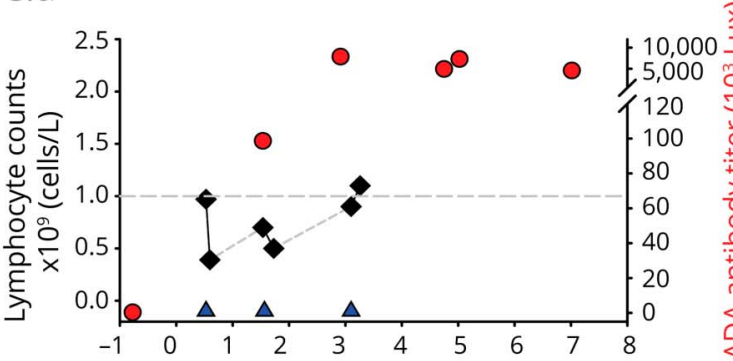

D.a

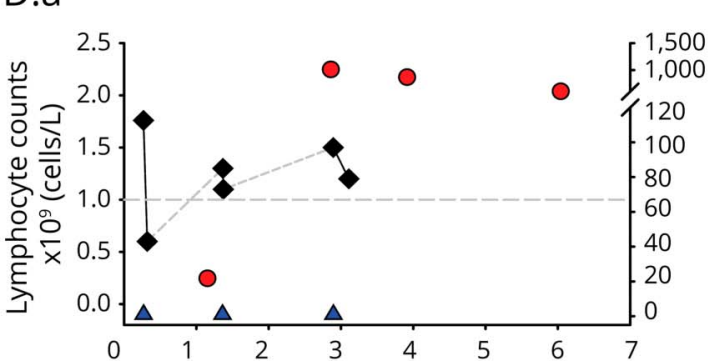

E.a

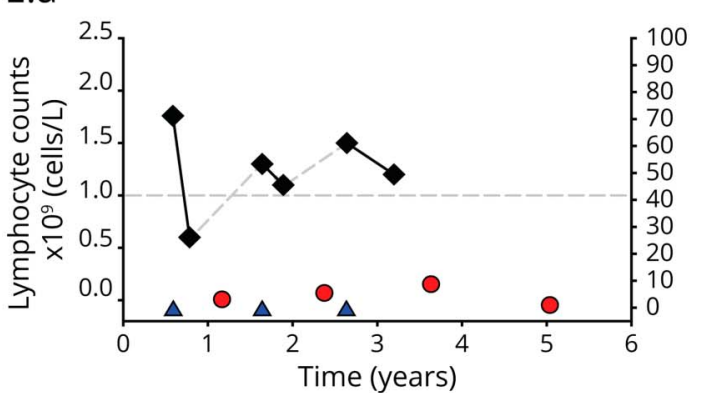

A.b

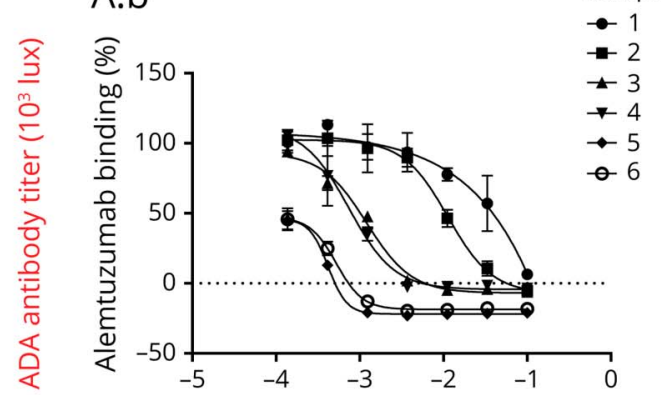

B.b

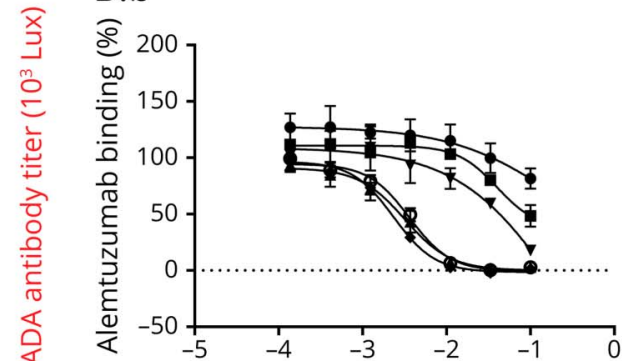

C.b

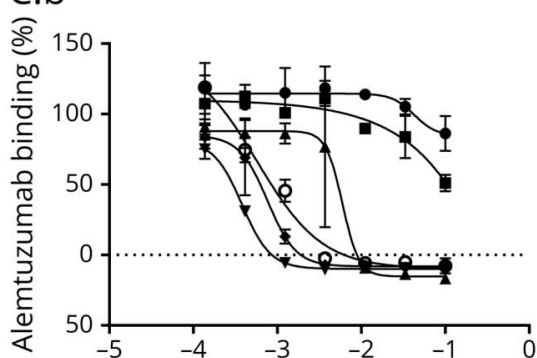

D.b

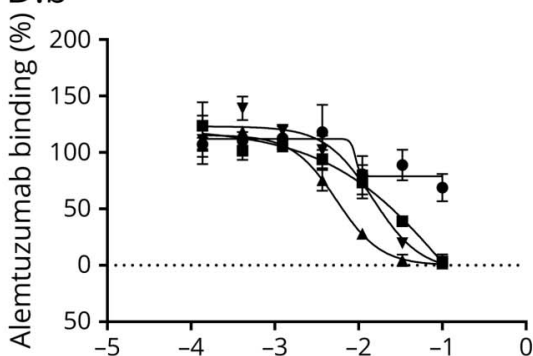

E.b

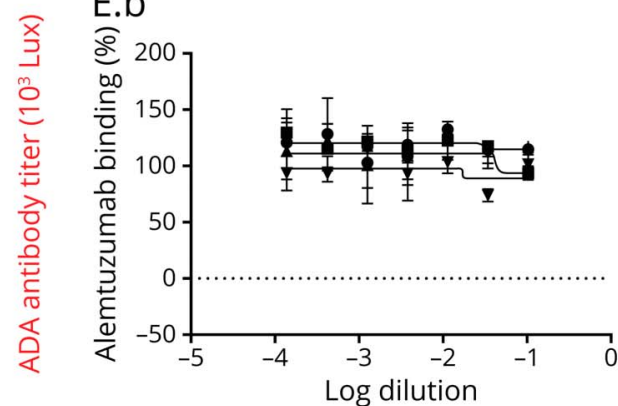

The (A.a-E.a) binding and (A.b-E.b) neutralizing responses of 5 individuals treated with alemtuzumab. (A.a-E.a) The results show the time of the beginning of each alemtuzumab infusion cycle, the absolute lymphocyte numbers, and the binding ADA titer or the neutralizing responses. (A.a-E.a) Lower limit of normal of lymphocyte number (dashed line). In (A.b-E.b), samples 1-6 or 1-4 are from the same individual at sequential time points during follow-up. Year 0 indicates 1 January of the year of the initial dosing and the time of treatments and sampling during the year are indicated. ADA = antidrug antibody; PwMS = people with MS. 
Figure 4 Alemtuzumab binding and neutralizing responses in people treated with alemtuzumab to predict treatment response
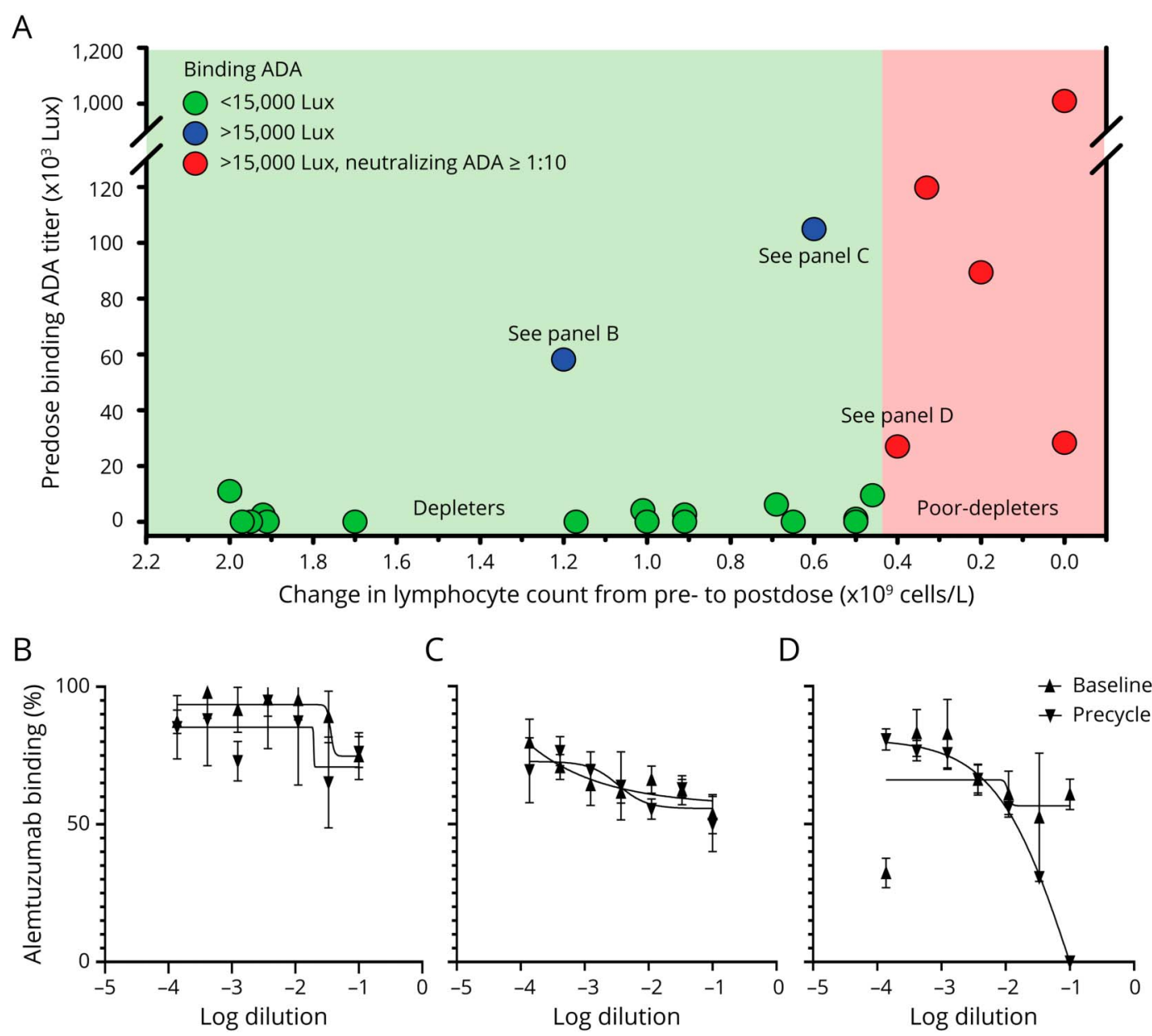

Alemtuzumab GloBody and alemtuzumab Alexa Fluor 488 conjugates were used to detect (A) a combination of binding and neutralizing ADA or (B-D) neutralizing ADA in sera from PwMS who had received alemtuzumab. (A) The binding ADA response in individual samples taken within 2 months before infusion and the level of lymphocyte depletion within 2 months postinfusion compared with the preinfusion level from cycles $1-4$. The neutralizing response was tested in individuals with a binding ADA level <15,000 lux (green) and >15,000 lux (red and blue). Those with a titer above a 1:10 serum dilution that essentially completely neutralized the alemtuzumab Alexa Fluor 488 binding response are indicated (red). Poor depleters were classified, before analysis, as those exhibiting less than a $0.4 \times 10^{9}$ cells/L depletion. Individuals with high-titer binding ADA who depleted peripheral blood lymphocytes (blue) were found $(B$ and $C$ ) to lack notable neutralizing ADA responses, seen in individuals exhibiting poor depletion (red. 4D). ADA = antidrug antibody; PwMS = people with MS.

data may help to validate and extend our findings and identify the important perturbations of the immune networks that facilitate ADA formation. ${ }^{7}$ Importantly, reevaluation of samples and data from CARE-MS and their extension studies, ${ }^{7,8,19}$ which contains immunophenotyping and $\mathrm{ADA}$ data, ${ }^{7}$ may provide further valuable insights into the relationship between both binding and neutralizing (inhibitory) antibody titers and the associated laboratory/clinical data. This may be particularly enhanced if events within lymphoid tissues can be also monitored, as they are the probably the source of $\mathrm{ADA}$ forming cells and are likely to deplete and repopulate differently to the peripheral blood. ${ }^{27,28}$ Previous reports of a lack of association between $\mathrm{ADA}$ and lymphocyte depletion at the population level ${ }^{10,12,15}$ are misleading because population analyses are insensitive to low frequency events, as demonstrated here. The influence of neutralizing $\mathrm{ADAs}$ alone has yet to be reported from the pivotal trial extension data, but people with the highest quartile of predose $\mathrm{ADA}$ producers deplete their lymphocytes postdose less efficiently than people in the lower $75 \%$ percentile, ${ }^{19}$ and suggests that analysis of the neutralizing response may be informative for treatment response in some individuals. Therefore, the neutralizing ADA data from the pivotal trial extension studies should be reported. Future work may also further define levels of ADAs that are predictive of disease activity.

The lack of general awareness of the potential of alemtuzumab to induce neutralizing antibodies, coupled with the suggestion that disease activity is not related to lymphocyte levels, ${ }^{29}$ may contribute to viewing lymphocyte depletion data as being unimportant. However, a failure of lymphocyte depletion is likely to imply that alemtuzumab is less effective. Once an individual failed to deplete, this was often seen in subsequent treatment cycles. Although it will be the case that only a small 
subset of lymphocytes will be clinically important and these will not be accurately monitored by simply measuring lymphocyte numbers, a lack of absolute lymphocyte depletion should prompt extra vigilance.

Our study provides important preliminary data that preinfusion binding $\mathrm{ADA}$ titers $>15,000$ and/or complete neutralization at $>10$ fold dilution may be associated with poor postinfusion lymphocyte depletion. Furthermore, this appears to be a predictor for future disease activity and the need for further alemtuzumab infusions. Therefore, monitoring ADA before the second or subsequent infusion cycles may be valuable in guiding treatment decisions. The ADA detection technology used here could also be applied to other monoclonal antibody treatments to inform whether to retreat or to switch therapy. Identifying people who are at risk of ineffective treatment responses might save them from undergoing an expensive and futile treatment and ensure cost-effective use of alemtuzumab.

\section{Study funding}

The study supported by a Rod Flowers Summer Vacation Scholarship to G. Saxena. L. Ali sincerely thanks National University of Medical Sciences Rawalpindi for the award of a visiting fellowship in collaboration with Queen Mary University of London.

\section{Disclosure}

The authors declare that the research was conducted in the absence of any commercial or financial relationships. G. Saxena, J.M. Moore, M. Jones, G. Pryce, L. Ali, G.R. Leisegang, V. Vijay, and S. Loveless have nothing to declare. However, A.S. Kang has trademarked GloBody and filed patents for potential commercial development related to the GloBody ADA technology. G. Giovannoni, S. Gnanapavan, K. Schmierer, E.C. Tallantyre, and N.P. Robertson have received consultancy, meetings, and/or grant support (S. Gnanapavan and N.P. Robertson) from Sanofi Genzyme, otherwise none are considered relevant. However, S. Gnanapavan has received travel support, consultancy fees, or grant support from Biogen, Novartis, Teva, Pfizer, and Takeda. D. Baker has received consultancy and presentation fees from Canbex Therapeutics, Japan Tobacco, Merck, Novartis, and Roche. K. Schmierer has received consultancy and presentation fees from Biogen, Bayer HealthCare, Lipomed, MedDay, Merck, Novartis, Roche, and Teva. G.Giovannoni has received consultancy, presentation fees, or grants from AbbVie Biotherapeutics, Actelion, Atara Bio, Biogen, Canbex, Celgene, Genentech, Japan Tobacco, Merck, Novartis, Roche, Sanofi Genzyme, Synthon, Takeda, and Teva. E.C.Tallantyre has received honoraria and meeting support from Merck, Novartis, Biogen, and Roche. N.P. Robertson has received personal fees and other from Biogen, Merck, Novartis, Roche, and Teva. Go to Neurology.org/NN for full disclosures.

\section{Publication history}

Received by Neurology: Neuroimmunology \& Neuroinflammation January 10, 2020. Accepted in final form April 13, 2020.

\section{Appendix Authors}

\begin{tabular}{|c|c|c|}
\hline Name & Institution & Contribution \\
\hline $\begin{array}{l}\text { Gauri Saxena, } \\
\text { BSc }\end{array}$ & $\begin{array}{l}\text { Blizard Institute, Barts } \\
\text { and The London School of } \\
\text { Medicine and Dentistry, } \\
\text { Queen Mary University of } \\
\text { London, United Kingdom }\end{array}$ & $\begin{array}{l}\text { Generated the assay } \\
\text { reagents, assays, data } \\
\text { analysis, and contributed } \\
\text { to the final manuscript }\end{array}$ \\
\hline $\begin{array}{l}\text { James M. } \\
\text { Moore, MBBS }\end{array}$ & $\begin{array}{l}\text { Division of Psychological } \\
\text { Medicine and Clinical } \\
\text { Neurosciences, Cardiff } \\
\text { University School of } \\
\text { Medicine, United } \\
\text { Kingdom }\end{array}$ & $\begin{array}{l}\text { Patient selection and } \\
\text { blinding of samples, } \\
\text { regulatory issues and } \\
\text { sample transfer, data } \\
\text { analysis, and contributed } \\
\text { to the final manuscript }\end{array}$ \\
\hline $\begin{array}{l}\text { Meleri Jones, } \\
\text { PhD }\end{array}$ & $\begin{array}{l}\text { Blizard Institute, Barts } \\
\text { and The London School of } \\
\text { Medicine and Dentistry, } \\
\text { Queen Mary University of } \\
\text { London, United Kingdom }\end{array}$ & $\begin{array}{l}\text { Assays and contributed to } \\
\text { the final manuscript }\end{array}$ \\
\hline
\end{tabular}

\begin{tabular}{lll}
\hline $\begin{array}{l}\text { Gareth Pryce, } \\
\text { PhD }\end{array}$ & $\begin{array}{l}\text { Blizard Institute, Barts } \\
\text { and The London School of } \\
\text { Medicine and Dentistry, } \\
\text { Queen Mary University of } \\
\text { London, United Kingdom }\end{array}$ & $\begin{array}{l}\text { Assays and contributed to } \\
\text { the final manuscript }\end{array}$ \\
\hline Liaqat Ali, PhD & $\begin{array}{l}\text { Blizard Institute, Barts } \\
\text { and The London School of } \\
\text { Medicine and Dentistry, } \\
\text { Queen Mary University of } \\
\text { London, United Kingdom } \\
\text { and Department of } \\
\text { Biological Sciences, }\end{array}$ & $\begin{array}{l}\text { Generated the assay } \\
\text { reagents, assays, and } \\
\text { contributed to the final } \\
\text { mational University of } \\
\text { Medical Sciences, } \\
\text { Rawalpindi, Pakistan. }\end{array}$ \\
\hline
\end{tabular}

\begin{tabular}{|c|c|c|}
\hline $\begin{array}{l}\text { Georgia R. } \\
\text { Leisegang, MSc }\end{array}$ & $\begin{array}{l}\text { Blizard Institute, Barts and } \\
\text { The London School of } \\
\text { Medicine and Dentistry, } \\
\text { Queen Mary University of } \\
\text { London, United Kingdom } \\
\text { and Centre for Oral } \\
\text { Immunobiology and } \\
\text { Regenerative Medicine, } \\
\text { Institute of Dentistry, Barts } \\
\text { and The London School of } \\
\text { Medicine and Dentistry, } \\
\text { Queen Mary University of } \\
\text { London, United Kingdom }\end{array}$ & $\begin{array}{l}\text { Generated the assay } \\
\text { reagents, assays, and } \\
\text { contributed to the final } \\
\text { manuscript }\end{array}$ \\
\hline $\begin{array}{l}\text { Vivek Vijay, } \\
\text { MBBS }\end{array}$ & $\begin{array}{l}\text { Blizard Institute, Barts } \\
\text { and The London School of } \\
\text { Medicine and Dentistry, } \\
\text { Queen Mary University of } \\
\text { London, United Kingdom }\end{array}$ & $\begin{array}{l}\text { Regulatory issues and } \\
\text { sample transfer and } \\
\text { contributed to the final } \\
\text { manuscript }\end{array}$ \\
\hline $\begin{array}{l}\text { Samantha } \\
\text { Loveless, PhD }\end{array}$ & $\begin{array}{l}\text { Division of Psychological } \\
\text { Medicine and Clinical } \\
\text { Neurosciences, Cardiff } \\
\text { University School of } \\
\text { Medicine, United Kingdom } \\
\text { and Welsh Neuroscience } \\
\text { Research Tissue Bank, } \\
\text { Cardiff University, United } \\
\text { Kingdom }\end{array}$ & $\begin{array}{l}\text { Patient selection and } \\
\text { blinding of samples, } \\
\text { regulatory issues and } \\
\text { sample transfer, tissue } \\
\text { banking, assays, and } \\
\text { contributed to the final } \\
\text { manuscript }\end{array}$ \\
\hline $\begin{array}{l}\text { Neil P. } \\
\text { Robertson, MD }\end{array}$ & $\begin{array}{l}\text { Division of Psychological } \\
\text { Medicine and Clinical } \\
\text { Neurosciences, Cardiff } \\
\text { University School of } \\
\text { Medicine, United } \\
\text { Kingdom and Welsh } \\
\text { Neuroscience Research } \\
\text { Tissue Bank, Cardiff } \\
\text { University, United } \\
\text { Kingdom }\end{array}$ & $\begin{array}{l}\text { Conceived the concept, } \\
\text { tissue banking, and } \\
\text { contributed to the final } \\
\text { manuscript }\end{array}$ \\
\hline
\end{tabular}


Appendix (continued)

\begin{tabular}{ll}
\hline Name & Institution \\
\hline Klaus & Blizard Institute, Barts \\
Schmierer, & and The London School of \\
PhD & Medicine and Dentistry, \\
& Queen Mary University of \\
& London, United Kingdom \\
& and Clinical Board: \\
& Medicine (Neuroscience), \\
& The Royal London \\
& Hospital, Barts Health \\
& NHS Trust, United \\
& Kingdom
\end{tabular}

\section{Contribution}

Provided standards and

clinical samples for assay

validation and

contributed to the final

manuscript

Gavin

PhD
Blizard Institute, Barts and The London School of

Medicine and Dentistry,

London, United Kingdom

and Clinical Board:

The Royal London

Hospital, Barts Health

NHS Trust, United

Kingdom

\section{Sharmilee Gnananpavan,} PhD Blizard Institute, Barts and The London School of Medicine and Dentistry,
Queen Mary University of

Medicine (Neuroscience),

Provided standards and clinical samples for assay validation, regulatory issues and sample transfer, and contributed to the final manuscript

Provided standards and Queen Mary University of London, United Kingdom and Clinical Board:

Medicine (Neuroscience), The Royal London Hospital, Barts Health NHS Trust, United Kingdom

\begin{tabular}{ll}
\hline $\begin{array}{l}\text { David Baker, } \\
\text { PhD }\end{array}$ & $\begin{array}{l}\text { Blizard Institute, Barts } \\
\text { and The London School of } \\
\text { Medicine and Dentistry, } \\
\text { Queen Mary University of } \\
\text { London, United Kingdom }\end{array}$ \\
& $\begin{array}{l}\text { Division of Psychological } \\
\text { Emma C. }\end{array}$ \\
$\begin{array}{l}\text { Mallantyre, } \\
\text { PhD }\end{array}$ & $\begin{array}{l}\text { Neurosciences, Cardiff } \\
\text { University School of } \\
\text { Medicine, United } \\
\text { Kingdom }\end{array}$ \\
\end{tabular}

Conceived the concept drafted the initial manuscript, data analysis, and contributed to the final manuscript

Conceived the concept, drafted the initial manuscript, patient selection and blinding of samples, regulatory issues and sample transfer, tissue banking, data analysis, and contributed to the final manuscript

\begin{tabular}{|c|c|c|}
\hline $\begin{array}{l}\text { Angray S. Kang, } \\
\text { PhD }\end{array}$ & $\begin{array}{l}\text { Blizard Institute, Barts } \\
\text { and The London School of } \\
\text { Medicine and Dentistry, } \\
\text { Queen Mary University of } \\
\text { London, United Kingdom } \\
\text { and Centre for Oral } \\
\text { Immunobiology and } \\
\text { Regenerative Medicine, } \\
\text { Institute of Dentistry, } \\
\text { Barts and The London } \\
\text { School of Medicine and } \\
\text { Dentistry, Queen Mary } \\
\text { University of London, } \\
\text { United Kingdom }\end{array}$ & $\begin{array}{l}\text { Conceived the concept, } \\
\text { drafted the initial } \\
\text { manuscript, designed the } \\
\text { GloBody molecules and } \\
\text { assays, generated the } \\
\text { assay reagents, assays, } \\
\text { data analysis, and } \\
\text { contributed to the final } \\
\text { manuscript }\end{array}$ \\
\hline
\end{tabular}

\section{References}

1. Willis MD, Robertson NP, Alemtuzumab for multiple sclerosis. Curr Neurol Neurosci Rep 2016;16:84.

2. Waldmann H, Hale G. CAMPATH: from concept to clinic. Philos Trans R Soc Lond B Biol Sci 2005;360:1707-1711.

3. Havrdova E, Arnold DL, Cohen JA, et al. Alemtuzumab CARE-MS I 5-year follow-up: durable efficacy in the absence of continuous MS therapy. Neurology 2017;89:1107-1116.

4. Coles AJ, Cohen JA, Fox EJ, et al. Alemtuzumab CARE-MS II 5-year follow-up: efficacy and safety findings. Neurology 2017;89:1117-1126.

5. Willis MD, Harding KE, Pickersgill TP, et al. Alemtuzumab for multiple sclerosis: long term follow-up in a multi-centre cohort. Mult Scler 2016;22:1215-1223.

6. Riechmann L, Clark M, Waldmann H, Winter G. Reshaping human antibodies for therapy. Nature 1988;332:323-327.

7. Baker D, Herrod SS, Alvarez-Gonzalez C, Giovannoni G, Schmierer K. Interpreting lymphocyte reconstitution data from the pivotal phase 3 trials of alemtuzumab. JAMA Neurol 2017;74:961-969.

8. Dubuisson N, Baker D, Kang AS, et al. Alemtuzumab depletion failure can occur in multiple sclerosis. Immunology 2018;154:253-260.

9. Coles AJ, Wing M, Smith S, et al. Pulsed monoclonal antibody treatment and autoimmune thyroid disease in multiple sclerosis. Lancet 1999;354:1691-1695.

10. CAMMS223 Trial Investigators; Coles AJ, Compston DAS, Selmaj KW, et al. Alemtuzumab vs. interferon beta-1a in early multiple sclerosis. N Engl J Med 2008; 359:1786-1801.

11. Cohen JA, Coles AJ, Arnold DL, et al. Alemtuzumab versus interferon beta 1a as firstline treatment for patients with relapsing-remitting multiple sclerosis: a randomised controlled phase 3 trial. Lancet 2012;380:1819-1828.

12. Coles AJ, Twyman CL, Arnold DL, et al. Alemtuzumab for patients with relapsing multiple sclerosis after disease-modifying therapy: a randomised controlled phase 3 trial. Lancet 2012;380:1829-1839.

13. Coles AJ, Waldmann H, Hale G. Inducing Tolerance to Campath-1H (Alemtuzumab) in the Treatment of Multiple Sclerosis. European Immunogenicity Platform; 2012: Available at: e-i-p.eu/ wp-content/uploads/2013/02/04_Alasdair_Coles_presentation.pdf. Accessed March 8, 2020.

14. Li Z, Richards S, Surks HK, Jacobs A, Panzara MA, Clinical pharmacology of alemtuzumab, an anti-CD52 immunomodulator, in multiple sclerosis. Clin Exp Immunol 2018;194:295-314.

15. Tuohy O, Costelloe L, Hill-Cawthorne G, et al. Alemtuzumab treatment of multiple sclerosis: long-term safety and efficacy. J Neurol Neurosurg Psychiatry 2015;86:208-215

16. Saxena GK, Theocharopoulos I, Aziz NT, et al. GloBody technology: detecting antidrug antibody against VH/VL domains. Sci Rep 2020;10:1860.

17. Ali L, Saxena G, Jones M, et al. A cell-based assay for the detection of neutralizing antibodies against alemtuzumab. Biotechniques 2020;68:185-190.

18. Harding $\mathrm{K}$, Williams $\mathrm{O}$, Willis $\mathrm{M}$, et al. Clinical outcomes of escalation vs early intensive disease-modifying therapy in patients with multiple sclerosis. JAMA Neurol 2019;76:536-541.

19. Jacobs A, Chung L, Yu Q, Firmini I. Minimal impact of anti-alemtuzumab antibodies on the pharmacodynamics and efficacy of alemtuzumab in RRMS patients from the CARE-MS studies-P611. Mult Scler 2018;24:302.

20. Selmaj KW, Bass AD, Edwards KR, et al. Lymphocyte pharmacodynamics and safety of fingolimod use in patients previously treated with alemtuzumab-F3151. Eur J Neurol 2015;22(suppl 1):759.

21. Rowan W, Tite J, Topley P, Brett SJ. Cross-linking of the CAMPATH-1 antigen (CD52) mediates growth inhibition in human B- and T-lymphoma cell lines, and subsequent emergence of CD52-deficient cells. Immunology 1998;95:427-436.

22. Brett SJ, Baxter G, Cooper H, Emergence of CD52-, glycosylphosphatidylinositolanchor-deficient lymphocytes in rheumatoid arthritis patients following Campath-1H treatment. Int Immunol 1996;8:325-334.

23. Oko A, Wyrwicz LS, Glyda M, et al. CD52 gene polymorphism and its potential effect on the response to alemtuzumab in renal transplant recipients. Ann Acad Med Stetin 2009;55:22-26.

24. Stewart R, Hammond SA, Oberst M, Wilkinson RW. The role of Fc gamma receptors in the activity of immunomodulatory antibodies for cancer. J ImmunoTherapy Cancer 2014;2:29.

25. Keller CW, Ruck T, et al. Impact of FcgammaR variants on the response to alemtuzumab in multiple sclerosis. Ann Clin Transl Neurol 2019;6:2586-2594.

26. Baker D, Ali L, Saxena G, et al. The irony of humanization: alemtuzumab, the first, but one of the most immunogenic, humanized monoclonal antibodies. Front Immunol 2020;11:124.

27. Turner MJ, Lamorte MJ, Chretien N, et al. Immune status following alemtuzumab treatment in human CD52 transgenic mice. J Neuroimmunol 2013;261:29-36.

28. Baker D, Pryce G, Amor S, Giovannoni G, Schmierer K. Learning from other autoimmunities to understand targeting of B cells to control multiple sclerosis. Brain 2018;141:2834-2847.

29. Kousin-Ezewu O, Azzopardi L, Parker RA, et al. Accelerated lymphocyte recovery after alemtuzumab does not predict multiple sclerosis activity. Neurology 2014;82: $2158-2164$. 


\title{
Neurology \\ Neuroimmunology \& Neuroinflammation
}

\author{
Detecting and predicting neutralization of alemtuzumab responses in MS \\ Gauri Saxena, James M. Moore, Meleri Jones, et al. \\ Neurol Neuroimmunol Neuroinflamm 2020;7; \\ DOI 10.1212/NXI.0000000000000767
}

This information is current as of June 4, 2020

\section{Updated Information \& Services \\ References \\ Subspecialty Collections}

Permissions \& Licensing

Reprints including high resolution figures, can be found at:

http://nn.neurology.org/content/7/4/e767.full.html

This article cites 28 articles, 1 of which you can access for free at: http://nn.neurology.org/content/7/4/e767.full.html\#\#ref-list-1

This article, along with others on similar topics, appears in the following collection(s):

All Clinical Neurology

http://nn.neurology.org//cgi/collection/all_clinical_neurology

Autoimmune diseases

http://nn.neurology.org//cgi/collection/autoimmune_diseases

Multiple sclerosis

http://nn.neurology.org//cgi/collection/multiple_sclerosis

Outcome research

http://nn.neurology.org//cgi/collection/outcome_research

Patient safety

http://nn.neurology.org//cgi/collection/patient_safety

Information about reproducing this article in parts (figures,tables) or in its entirety can be found online at:

http://nn.neurology.org/misc/about.xhtml\#permissions

Information about ordering reprints can be found online:

http://nn.neurology.org/misc/addir.xhtml\#reprintsus

Neurol Neuroimmunol Neuroinflamm is an official journal of the American Academy of Neurology.

Published since April 2014, it is an open-access, online-only, continuous publication journal. Copyright

Copyright (C) 2020 The Author(s). Published by Wolters Kluwer Health, Inc. on behalf of the American

Academy of Neurology.. All rights reserved. Online ISSN: 2332-7812.

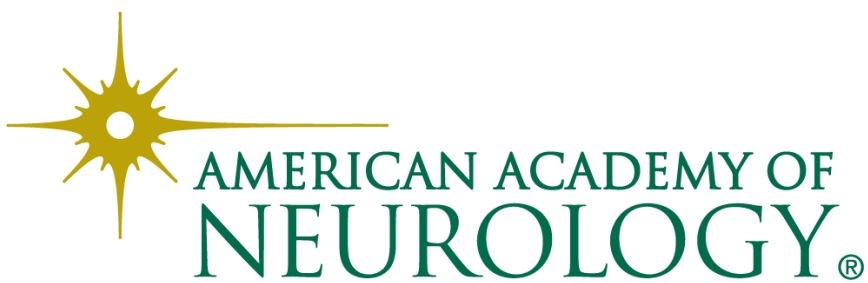

